\title{
Water and Sanitation Management: During and after COVID-19 Pandemic
}

\author{
Soumya Kar, Rajiv Gupta** \\ Civil Engineering Department, Birla Institute of Technology and Science, Pilani 333 031, Rajasthan, India \\ *Corresponding author: E-mail: rajiv@pilani.bits-pilani.ac.in \\ DOI: $10.5185 /$ amlett.2020.111570
}

Pandemics have threatened human civilization time and again. Currently, the whole world is dealing with COVID-19, a never seen situation in a hundred years, after the deadly Spanish Flu during 1918-1920. With no specific medicines or vaccines, the best way to keep infections under control is by maintaining personal hygiene and social distancing, as per WHO guidelines. Hygiene and sanitization are ensured with clean water, a highly stressed resource in today's times. In this perspective, we try to cover the immediate management of water resources and sanitation facilities in stalling the spread of the pandemic.

Further, suggestions regarding robust water and sanitation infrastructure and management practices have been discussed that can be adopted by the administration and modified as per local requirements. This pandemic is no less than a disaster, though not natural, but ecological. Past epidemics are pointing towards an increase in the occurrence of a public health crisis of current magnitude and more. This calls for a paradigm shift towards development and preparedness.

\section{Introduction}

The whole world today has come to a standstill fighting an invisible enemy. The enemy is a microscopic organism; a virus, causing a respiratory disease, COVID-19. With over 7 million affected globally, it was declared a pandemic by the World Health Organisation (WHO) on 11 March 2020. Pandemic originates from the Greek work Pandemos, meaning pan 'all' and demos 'people'. Historically, the world has been hit by several pandemics, killing millions, and often changing the course of history and sometimes ravaging entire civilizations. Some of the deadliest epidemics / pandemics recorded have been tabulated in Table 1.

Be it cholera or Spanish Flu; in the years 1852 and 1918, respectively, pandemics have ravaged the Earth killing millions. Still, with all the advancements made in the field of medical and technological sciences, we are neither able to predict an outbreak nor contain the spread of infection. This describes the very nature of a pandemic, unpredictable, and uncontainable. The present pandemic, 2019-nCoV or COVID-19 (renamed) is a contagious viral pneumonia, with a fatality rate of $5.45 \%$, is caused by SARS-CoV-2, a member of the coronavirus family.

Table 1. List of some of the worst epidemics / pandemics in recorded history.

\begin{tabular}{|c|c|c|c|c|}
\hline Name of epidemic/ pandemic & Time Period & Cause of infection & Places affected & No of people killed \\
\hline The Black Death & $1346-1353$ & Bubonic Plague (Yersinia pestis) & Asia and Europe & $75-200$ million \\
\hline Cocoliztli epidemic & $1545-1548$ & S. paratyphi $C$ & Mexico and Central America & 15 million \\
\hline Great plague of London & $1665-1666$ & Yersinia pestis & Great Britain & 1 million \\
\hline Cholera Pandemic & $1852-1860$ & Vibrio cholerae & $\begin{array}{l}\text { Asia, Europe, North America and } \\
\text { Africa }\end{array}$ & $>1$ million \\
\hline Flu Pandemic or Russian Flu & $1889-1890$ & H3N8 strain of Influenza A & Majority of the world & 1 million \\
\hline Spanish Flu & $1918-1920$ & H1N1 strain of Influenza & Majority of the World & $>50$ million \\
\hline Asian Flu & $1956-1958$ & $\mathrm{H} 2 \mathrm{~N} 2$ strain of Influenza A virus & $\begin{array}{l}\text { China, Singapore, Hong Kong, } \\
\text { U.S.A. }\end{array}$ & 2 million \\
\hline $\begin{array}{l}\text { Flu Pandemic or Hong Kong } \\
\text { Flu }\end{array}$ & 1968 & H3N2 strain of Influenza A virus & $\begin{array}{l}\text { Hong Kong, Singapore, Vietnam, } \\
\text { The Philippines, India, Australia, } \\
\text { Europe, and the United States }\end{array}$ & $>1$ million \\
\hline AIDS & 1981-present day & $\begin{array}{l}\text { H.I.V. (Human immunodeficiency } \\
\text { virus) }\end{array}$ & Majority of the world & 35 million \\
\hline Swine Flu & $2009-2010$ & H1N1 strain of Influenza & Majority of the world & $\begin{array}{l}\text { Between } 151,700 \\
\text { and } 575,400\end{array}$ \\
\hline West African Ebola & 2014-2016 & Zaire ebolavirus & $\begin{array}{l}\text { West Africa, the United States, } \\
\text { and Europe }\end{array}$ & 11,325 \\
\hline Zika & 2015-present day & Zika virus & $\begin{array}{l}\text { South America, Central America } \\
\text { and parts of the southern United } \\
\text { States }\end{array}$ & Unknown \\
\hline COVID-19 & 2019-continuing & SARS-CoV-2 & Entire World & 0.14 million till date \\
\hline
\end{tabular}

Source: Centers for Disease Control and Prevention (Accessed on 16 April 2020). 


\section{Advanced Materials Letters www.vbripress.com/aml}

COVID-19 is a respiratory disease similar to the SARS with reported symptoms such as dry cough, fever, fatigue, myalgia, and, in some cases, dyspnoea. Transmission of coronavirus typically occurs by touching an infected surface and mediating through nose, mouth, and eyes, and, proximity to an infected person (inhalation of exhaled virus in respiratory droplets) [1]. Earlier coronaviruses were responsible for severe acute respiratory syndrome (SARS) and the Middle East respiratory syndrome (MERS) outbreaks in the year 2003 and 2012, respectively. Coronaviruses are a class of enveloped positive-sense single-stranded RNA viruses that originate in animals and cause diseases in humans, hence classified as zoonotic [2]. The Centres for Disease Control and Prevention (CDC.) estimates that three-quarters of the "new or emerging" diseases that infect human beings are zoonotic.

With little knowledge about the virus, no specific medicine or vaccine to date and increasing cases of infections, the existing health infrastructure, and medical staff and sanitary workers are overwhelmed the world over [3]. Controlling the pandemic can be achieved by preventing the spread of infections. The World Health Organization has led down specific guidelines for the prevention of the spread of the virus, which includes frequent hand washing, sanitization of articles, social distancing, avoiding touching of eyes, nose, and mouth and practicing respiratory hygiene [4]. With over a billion people having no access to clean water, some of the proposed guidelines, like hand washing, sanitizing surfaces, and cleaning infected articles, is far from reality. The importance of safe water supply and sanitation systems is documented since ancient times (ca. 3200-1100 BC) [5]. Civilizations have flourished along the banks of major rivers. The Indus valley civilization, which flourished during the Bronze Age, had excellent water systems, such as aqueducts, cisterns, filtering systems, sedimentation basins, rainfall-harvesting systems, terracotta pipes for water supply and sewage, and the sewerage and drainage systems [6]. However, with a boom in industrialization, globalization, and expansive agricultural practices, along with the rapidly increasing world population, the dependency on the limited supply of water we have has increased. Agricultural practices (including irrigation, livestock, and aquaculture) consume around $69 \%$ of the global water use, followed by industrial and municipal (including domestic) at $19 \%$ and $12 \%$, respectively $[\mathbf{7 , 8}]$. All the above activities generate a significant amount of waste, which contaminate the water resources. Another cause of contamination of water bodies is open defecation, which affects almost 1 billion people globally, resulting in the death of around 8 lakh people annually due to sanitation-related diseases [9]. Even groundwater is not safe, as pollutants leach into aquifers.

Water and sanitation systems are essential infrastructure, shown in Fig.1, which underpin a community's health, safety and economic development [10]. In several developing economies the water and sanitation infrastructure is still not fully developed to cater to a large population. In India, $48 \%$ of urban households had access to piped water supply compared to 58\%, 67\% and 95\% households in Pakistan, Sri Lanka and China, respectively as of 2013 . Only $21 \%$ of wastewater generated in India was treated [11]. Not only urban, rural sanitation is severely affected due to lack of water for cleaning purposes, coupled with societal norms and traditional outlooks [12]. Though, developed countries fare better in terms of water and sanitation infrastructure, much of such infrastructure in the United States, Western Europe and several other places are aging and in need of serious replacement and there have been reports of sewer water directly discharging into rivers [13]. Though COVID-19 is primarily a respiratory disease, several studies have reported the presence of virus strains in the fecal sample of infected patients; and in city sewage well before confirmed cases of COVID-19 were reported, making the disease a promising candidate for wastewater based epidemiology [14-19]. Further, the presence of the virus in water is predicted up to a week. Spread through sanitation route is a major concern because of the last recorded SARS outbreak in Hong Kong in 2003 [20].

Contaminated water further increases the stress on the limited supply of freshwater and the increase in the spread of various water-borne diseases. Thus, the current challenge is the judicious use of water and enhanced global access to clean water supply, and safe sanitation facility, as has been aptly quoted by United Nations Secretary-General Kofi Annan, "Access to safe water, is a fundamental human need and, therefore, a basic human right. Contaminated water jeopardizes both the physical and social health of all people. It is an affront to human dignity".

\section{Immediate measures for controlling the spread of COVID-19 by the management of water and sanitation facilities}

Water: The priority given to handwashing with soap by WHO is significant as it kills the virus and other microbes, and controls the spread of infection. But then, a 20-second routine can consume up to 2 liters of water multiplied by an average of five times of handwashing, resulting in the usage of 10 liters of water per person. This is a large amount of water for people living in water-scarce and poor economy countries, rural districts, and urban slums [21].

i. With a majority of schools, universities, and commercial outlets closed, the water meant for those establishments can be diverted to slums in urban areas. Water tank mobility should be stimulated and a regular supply of water delivered to the rural areas to ensure improved handwashing.

ii. People should be encouraged to create temporary handwashing units like tippy tap and Tap-up sink, which will promote frequent handwashing [22]. The water generated from hand washing should be collected at every household, urban and rural, and reused for flushing toilets. This will save overburdening the water infrastructure and excessive wastage of water [23]. 

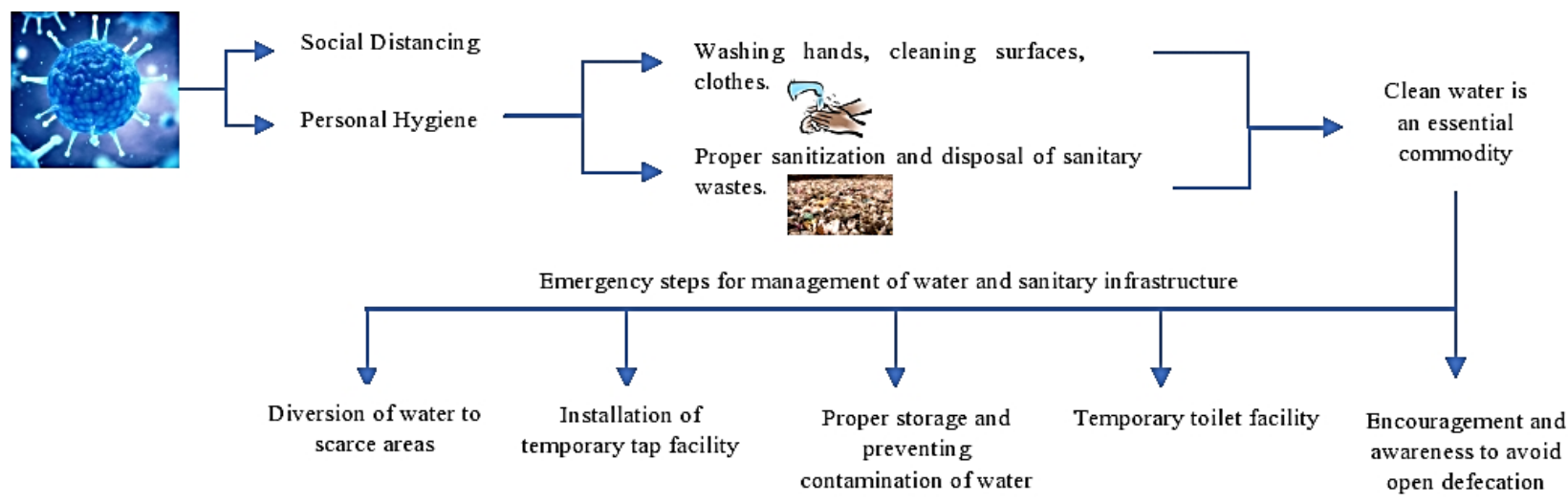

Fig. 1. Schematic representation of immediate water and sanitation infrastructure management.

iii. At village levels, where multiple households depend upon a single source like a tube well, bore well, or municipal tap, an agreement can be established among the houses mutually, to collect water in fixed time slots and avoid over-crowding and maintain social distancing.

iv. The inclusion of people with special needs in this war against COVID-19 is critical.

v. Boiling of water and treatment with chlorine should be advertised. Proper storage of drinking water should be maintained [4].

Sanitation: Open defecation is a big problem, particularly in rural areas and urban slums, where people have zero or limited access to sanitation facilities. If the human feces of an infected person (asymptomatic person) contaminates the water supply or infects people through any other way, the pandemic can create large scale infections and deaths within communities. Similarly, damaged sewer lines and plumbing can create new pathways for transmission of the virus.

i. Households already having sanitation facilities, be encouraged to use those facilities, and avoid open defecation.

ii. Slums need to be provided with temporary toilet facilities at the community level until the control of the pandemic to prevent over-crowding, whilst following social distancing.

iii. For households having no access to toilets, people should be encouraged to avoid defecating near water resources and cover their waste with soil to prevent contamination, like the cat method [24].

iv. Checking of faulty plumbing and damaged sewer lines, especially in hospitals and quarantine buildings, needs to be carried out on an urgent basis to prevent the spread of the virus through any other pathway (development of aerosols).

\section{Water and sanitation management: Mitigating measures towards future outbreak / disaster}

Water infrastructure deals with the collection, storage, treatment, and supply of water, while sanitation infrastructure includes the capture, storage, transport, treatment, and disposal or reuse of human excreta and wastewater. WASH is the collective term for Water, Sanitation, and Hygiene. UNICEF's WASH team works diligently in over 100 countries worldwide to improve water and sanitation services, as well as basic hygiene practices. Due to their interdependent nature, these three core issues are grouped to represent a growing sector. While each is a separate field of work, each is dependent on the presence of the other. For example, without toilets, water sources become contaminated; without clean water, basic hygiene practices are not possible [25]. Studies have proven the overall improvement in the health of communities where WASH and similar concepts have been applied [26]. With hand washing as a basic step to ensure cleanliness, the importance of water during the current pandemic cannot be questioned [27], while improved sanitation and waste management is a benchmark of a healthy community. This pandemic should force authorities, organisations and citizens alike to strive for a clean environment with better access to water and sanitation.

\section{Water}

i. Policies: Most of the water policies were made during a time when water supply was abundant. With changing times, these policies need to be updated. The involvement of Government and communities at the grassroots level is essential in ensuring the delivery of services to the poorest and not just the affluent. Creating water markets, ending the under-pricing of services, guarantee to the right to water, decentralizing the responsibility for water resources, developing know-how at local levels, improving financing by bringing in foreign aid $[\mathbf{2 8 , 2 9}]$. Continuous monitoring and evaluation of water resources are some areas where rigorous and renewed policies can be implemented.

ii. Awareness among masses: Basic hygiene and proper handwashing techniques should be imparted from the school level. The relation between unclean water and diseases should be advertised on media platforms in various regional languages by roping in celebrities. Community-level skits and plays should be organized to educate people. 
Advanced
Materials Letters
www.vbripress.com/aml

iii. Rainwater Harvesting System (RWHs): With dwindling groundwater reserves and polluted surface water, it is imperative to capture all the clean water that we receive through rains. A household having an inbuilt RWH, does not have to depend upon government water supply systems necessarily. RWHs reduces the stress upon main water supply lines and lessens runoff and contamination after rainfall. RWHs can be constructed both at household level and community level, with varying capacity depending upon the rainfall received at a place and the economic capability of the community. Household RWHs systems can help a family to meet their water demands for cooking, drinking, and cleaning during periods of dry spell. Excess rainfall can be diverted to the community tank with a larger capacity. Community tanks act as groundwater recharging structures and reserve during times of crisis. Government agencies and private firms can develop such tanks in partnership. RWH tanks can act as a cushion during periods of emergency thereby turning hazards (polluted water, epidemic) into local resources (water for individual uses) [30]. Both water scarce and water rich areas should aim towards storing as much water possible thereby reducing burden on piped networks. In case of future outbreaks, locally stored water (no combined sewage, no pollution) can give authority much needed time for remedial measures.

iv. Updated household water treatment infrastructure: Point of use (POU) water treatment and storage are very effective in reducing water contamination [31]. There are several treatment technologies available in the market, like RO (reverse osmosis) systems, Nanofiltration systems, UV (ultraviolet) systems that can remove impurities and microbes from water. However, these filters waste much water during the treatment process. Also, they require electricity for operation, which is not always feasible in rural areas and slums. Low-cost environment-friendly water filters should be distributed among households, which is both economical and effective in providing clean water. Since ceramic water filters are effective in removing bacteria and viruses, these can be used as POU's $[32,33]$. Biological methods such as Bio-remediation and bio-retention, chemical methods such as use of sunlight, $\mathrm{TiO}_{2}$, and alum, and physical processes such as hybrid staggered filters can be used for water purification [34-36].

v. Budget allocation for the development of water infrastructure: The governments should collectively allocate funds for the development of sturdy water infrastructure, like pipes, bore wells, reservoirs, and community water treatment units (decentralized). Reports suggest that the rural water sector works better in a decentralized structure [37]. Community participation is essential in the operation and maintenance of the decentralized structure. vi. Use of technology: A national database and surveillance system should be developed to document usage of water, depletion of resources, and water-borne disease outbreaks. Remote sensing and mobile application technology have significantly improved the crisis response phase for natural as well as humanitarian emergencies [38]. Therefore, the Geographical Information system (GIS) can be used in the development of a centralized database keeping track of water depletion levels, surface water pollution level, and dysfunctional treatment units. This will help in directing policies and treatment measures, where most needed. Wireless Network sensors can be adopted in checking the quality of water both at treatment and household level to ensure no contamination and effective monitoring $[\mathbf{3 9 , 4 0}]$.

\section{Sanitation}

i. Construction and education regarding household sanitation facility: The primary problem that needs to be dealt with is the lack of sanitation facilities, which forces people to defecate in the open. But construction of latrine is not the only solution. Studies have shown that people preferred open defecation, even after building pit latrines in and around their homes. Several factors influence their habits, such as undesirable toilet structure, cultural and traditional beliefs, absence of water connection, size of pits, lighting, proper ventilation, and other characteristics for comfort like a roof, door, and floor tiles. Other factor includes personal preference and gender psychological norms. The mindset of people can be changed by rigorous awareness programs, construction of toilets suitable to the needs of the user, and education about the uses and emptying of pits. Governments can partner with sanitation focused social enterprises to sell sanitation solutions ranging from basic latrines to eco-toilet [4143].

ii. Decentralized wastewater treatment system: Waste generated in urban areas and industries goes through wastewater treatment plants (WWT). But the load received is much higher than the capacity of the plant. So quick treatment is given to the sewage and dumped into river bodies. This practice severely contaminates water resources [44]. Decentralized wastewater treatment plants should be commissioned in multiple numbers to reduce load on city sewer plants. Decentralized wastewater management is inevitable for comprehensive sustainable wastewater treatment and environmental protection worldwide [45]. Nature and ecological based wastewater treatment systems are in use in several countries, providing for remote and rural locations. Such systems should be constructed by the Governments in commission with private firms and community participants, both at rural and urban locations, to increase the overall efficiency of WWT plants [46-48]. 


\section{Advanced Materials Letters www.vbripress.com/aml}

iii. Redesigning existing toilet infrastructures connected to grids: Households that are connected to a sewage grid should alter the designs of their toilets by attaching the gray water produced from handwashing to be used for the next flush. This saves much water, thereby reducing dependency on water and wastewater infrastructure.

iv. Technological usage: The functioning of centralized and decentralized WWT plants should be monitored through a shared database. This database gives concerned authorities the idea regarding the operation of the plants and timely maintenance and cleaning. Regular testing of sewage sample quality and microbial load can help in the detection of any future outbreak, thereby prompting preparedness.

v. Wastewater irrigation: Reuse of wastewater is essential in a developing country, struggling to meet its water demand. Development of design-for-service (DFS) concepts to enable the design of new treatment plants and rehabilitation of old ones with wastewater as a source for agriculture, can be initiated by mutual engagement of the Governments and communities. Research should be done to determine the quality of treated wastewater produced from decentralized and centralized WWT plant, and its safety to use in agriculture. This will reduce the dependence on groundwater.

(a) A special focus needs to be given to the handling of animal products in wet markets, which have recently come in scrutiny for their dealings of wildlife and unhygienic conditions resulting in the spread of zoonotic diseases [49]. The wastes generated from these markets contain blood, hair, skin, bones, excrement and a range of germs harmful to humans. Anaerobic and aerobic digestion of wet market wastewater, composting, and reuse of solid waste carbon for removal of heavy metal are some technical and economical alternatives [50,51].

\section{Conclusion}

The whole world is presently reeling under the effects of a pandemic. The current situation has affected every sector of human life and shattered the economy. With no cure and vaccine yet developed, the only way out of this situation is controlling the spread of infections. The World Health Organization has created guidelines to be followed to keep infections at bay. Frequent handwashing with soap and running water and sanitizing surfaces is one of the prescribed guidelines. But, water in today's world is a highly stressed resource, with over a billion people, having no access to clean water supply.

Clean water supply and safe sanitation are fundamental rights which can be achieved by coming together of world leaders, governments, and communities. A wellfunctioning water and sanitation infrastructure ensures the smooth running and survival of a community when disaster strikes until external aid arrives. Further, these basic infrastructure improves gender equality and reduces burden on the women. As has been discussed in the paper, various measures can be adopted for saving water and treating wastewater, both centrally and at the community level, thereby creating a robust locality. People of such a community have their supply of clean water, treatment plants, and food supplies grown with harvested water and treated wastewater.

Disasters; natural, ecological, and humanitarian, have struck human civilization repeatedly and continue to do so in the future. Preparedness is the only way forward for a safer world. Community participation is crucial in creating a robust infrastructure resistant to any untoward incident. Once the pandemic has passed, we should bring our united and undivided attention as a global community to improve infrastructure, global health, and climate.

According to Italian philosopher Emanuele Coccia, 'We inhabit not Earth but the atmosphere, which is described as a sea of life; and as swimmers in this sea, we, humans, cannot be biologically isolated. Neither can our ecological practices'. This pandemic has created a situation where we can introspect and improve our behavior towards the environment and learn to live with its resources coherently.

Declaration of competing interest

None declared.

Funding sources

None declared

\section{Keywords}

COVID-19, Geographical Information System (GIS), management, pandemic, rainwater harvesting, sanitation, water infrastructure.

\section{References}

1. Qu, G.; Li, X.; Hu, L.; Jiang, G.; Environ. Sci. Technol. 2020, 54, 3730 .

2. National Institute of Allergy and Infectious Diseases 2020. "COVID19, MERS \& SARS" NIH. https://www.niaid.nih.gov/diseasesconditions/covid-19 (accessed April 11, 2020).

3. Ebrahim, S. H.; Ahmed, Q. A.; Gozzer, E.; Schlagenhauf, P.; Memish, Z. A.; BMJ, 2020, 368, m1066.

4. World Health Organization. "Water, sanitation, hygiene and waste management for COVID-19. Technical brief, 19 March 2020", 2020.

5. Angelakis, A. N.; Dialynas, M. G.; Despotakis, V.; Evolution of Water Supply throughout Millennia, 2012, 227.

6. Angelakis, A. N.; Zheng, X.Y.; Water, 2015, 7, 455

7. Molden, D.; Oweis T.Y.; Pasquale, S.; Kijne, J. W.; Hanjra, M.A.; Bindraban, P.S.; Bouman et al.; EconPapers, 2007, No. 612-201640552.

8. Food and Agriculture Organization. "AQUASTAT-F.A.O's Global Information System on Water and Agriculture." UN. http://www.fao.org/aquastat/en/overview/methodology/water-use (accessed April 14, 2020)

9. WHO, Burden of Disease and Cost-Effectiveness Estimates, WHO, Water Sanitation and Health (WSH), Geneva, Switzerland, 2014.

10. Dasgupta, S.; Tam, E.K.L.; Can. J. Civ. Eng., 2005, 32, 30.

11. Wu, X.; House, R. S.; Peri, R.; Water Policy, 18, S1, 2016, 153.

12. Routray, P; Schmidt, W.P.; Boisson, S.; Clasen, T.; Jenkins, M.W.; BMC Public Health, 2015, 15, 880.

13. Sedlak David. "How Development of America's Water Infrastructure Has Lurched Through History." The PEW Charitable Trusts, March 3, 2019. Accessed June 16, 2020. https://www. pewtrusts.org/en/trend/archive/spring-2019/how-development-ofamericas-water-infrastructure-has-lurched-through-history 


\section{Advanced Materials Letters www.vbripress.com/aml}

14. Casanova, L.; Rutala, W.A.; Weber, D.J.; Sobsey, M.D.; Water Research, 2009, 43, 1893.

15. Gundy, P.M.; Gerba, C. P.; Pepper, I. L.; Food and Environmental Virology, 2009, 1, 10.

16. Lodder, W. J.; Van Den Berg, H. H. J. L.; Rutjes, S. A.; de Roda Husman, A. M.; Appl. Environ. Microbiol., 2010, 76, 5965.

17. Medema, G.; Heijnen, L.; Elsinga, G.; Italiaander, R.; Brouwer, A.; medRxiv, 2020.

18. Xiao, F.;Tang, M.; Zheng, X.; Liu, Y.; Li, X.; Shan, H.; Gastroenterology, 2020, 158, 1831.

19. Wu, F.; Xiao, A.; Zhang, J.; Gu, X.; Lee, W.L.; Kauffman, K.; Hanage, W. et al.; medRxiv, 2020.

20. Hung, L.S.; J. R. Soc. Med., 2003, 96, 374.

21. Kumar, Satish; "COVID-19: Water scarcity lurking in crisis?" Deccan Herald, March 29, 2020. Accessed April 10, 2020. https://www.deccanherald.com/national/covid-19-water-scarcitylurking-in-crisis-818856.html

22. Biran, A.; "Enabling technologies for handwashing with soap: a case study on the Tippy-Tap in Uganda." 2011.

23. Campisano, A.; Modica, C.; Urban Water J., 2010, 7, 17.

24. Osumanu, Issaka Kanton, Enoch Akwasi Kosoe, and Frank Ategeeng; J. Environ. Public Health, 20193075840

25. Unicef. "Water, Sanitation and Hygiene." UN. https://www.unicef.org/wash/3942_3952.html (accessed April 15, 2020)

26. Huttinger, A.; Dreibelbis, R.; Kayigamba, F.; Ngabo, F.; Mfura, L.; Merryweather, B.; Cardon, A.; Moe, C.; BMC Health Serv. Res., 2017, 17, 517

27. SenGupta, A.K.; Environ. Eng. Sci., 2020, 37, 393

28. Davis, Jenna, Gary White, Said Damodaron, Rich Thorsten. Water Science and Technology, 2008, 58, 887.

29. Botting, M.J.; Porbeni, E.; Joffres, M.R.; Johnston, B. C.; Black, R.; Mills, E.J.; Global Health, 2010, 6, 12.

30. Domènech, L.; Saurí D.; J. Cleaner Prod., 2011, 19, 598.

31. Pooi, C. K.; Ng, H. Y.; Npj Clean Water, 2018, 1,1 .

32. Soliman, M.Y.M.; Halem, D.V.; Medema, G.; Int. J. Hyg. Environ. Health, 2020, 224, 113438.

33. Laan, V. H.; Halem, D.V.; Smeets, P. W. M. H.; Soppe, A. I. A.; Kroesbergen, J.; Wubbels, G.; Nederstigt, J.; Gensburger, I.; and Heijman, S. G. J.; Water Research, 2014, 51, 47.

34. Salih, F. M. "Water Purification by a Combination of Sunlight, Titanium Dioxide, and Alum." In Critical Transitions in Water and Environmental Resources Management, 2004, pp. 1-9.

35. Aoyagi, Y.; Takeuchi, M.; Yoshida, K.; Kurouchi, M.; Yasui, N.; Kamiko, N.; Araki, T.; Nanishi, Y.; J. Environ. Eng., 2011, 137, 1215.

36. Wu, H.Z.; Hsu, Y.L.; Huang, H.L.; Chen, J.P.; Chen, C.S.; Lin, P.H.P.; Pract. Period. Hazard., Toxic, Radioact. Waste Manage. 2007, 11, 92.

37. Iyer, Parameswaran. Infrastructure and Investments in Water and Sanitation in India. PDF file. May 31 and June 1, 2018. http://ris.org.in/pdf/aiib/31May2018/Background_Note.pdf

38. Piero, B.; Tonolo, F.G.; Springer, Cham. 2015, 5, 17.

39. Pule, M.; Yahya, A.; Chuma, J.; (NICS), IEEE, 2016, 12.

40. Sridharan, S.; International Journal of Advanced Research in Electronics and Communication Engineering (IJARECE), 2014, 3, 399.

41. Mac, Karen. "A Human Centered Approach to Tackling India's Open Defecation Crisis", 2018.

42. O'Reilly, K.; Dhanju, R.; Goel, A.; World Development, 2017, 93, 193.

43. Spears, D.; Thorat, A.; Economic Development and Cultural Change, 2019, 67, 725.

44. Sahasranaman, M.; Ganguly, A.; "Wastewater Treatment for Water Security in India, 2018.

45. Al-Jamal, W.; Mahmoud, N.; Bioresour. Technol., 2009, 100, 1061.

46. Istenic, D.; Bodík, I.; Bulc T.; Environ. Sci. Pollut. Res., 2015, 22, 12884.

47. Son, Y.; Rhee, H.P.; Yoon, C.G.; Kwon, T. Y.; Desalin. Water Treat., 2016, 57, 20766.

48. Roefs, I.; Meulman, B.; Vreeburg, J.H.G.; Spiller. M.; Water Res., 2017, 109, 274.
49. Bao, C.J.; Cui, L.B.; Zhou, M.H.; Hong, L.; Gao, G.F.; Wang, H.; N. Engl. J. Med., 2013, 368, 2337.

50. Jian, T.; Zhang X.; Resour., Conserv. Recycl., 1999, 27, 145.

51. Arvanitoyannis, I.S.; Ladas, D.; Int. J. Food Sci. Technol., 2008, 43 , 543. 